\title{
The Effective Role of Phitofert ${ }^{\circledR}$ Supplement in Male Reproductive Hormones and Epididymal Sperm Quality in Carbon Tetrachloride (CCL4) Treated Rats
}

\author{
Wassan Mhammed Husain ${ }^{*}, Z_{\text {ainab Sattar Ali }}^{2}$ \\ ${ }^{1}$ College of health E medical technology, Uruk University, Iraq; ${ }^{2}$ College of Pharmacy-University of Al-Muthana, \\ Iraq.
}

\begin{abstract}
The goal of this study was to see if Phitofert ${ }^{\circledR}$ might help improve sperm function in carbon tetrachloride (CCL4) -treated and healthy adult rats. Twenty-four adult rats were randomly divided into four groups and given the following treatments for 28 days: G1: as a control, the animals were oral administration with DW. G2: healthy rats were given $0.035 \mathrm{mg} / \mathrm{kg} \mathrm{BW}$ of Phitofert ${ }^{\circledR}$ every day by gavage. G3: twice a week, they were given $500 \mathrm{mg} / \mathrm{kg} \mathrm{B.W}$. of CCL4 mixed with an equivalent volume of olive oil (o.5 ml $/ \mathrm{kg} \mathrm{B.W.).} \mathrm{G4:} \mathrm{were} \mathrm{treated} \mathrm{twice} \mathrm{a} \mathrm{week} \mathrm{with} 500 \mathrm{mg} /$ $\mathrm{kg} \mathrm{BW}$ of CCL4 mixed with an equivalent amount of olive oil ( $0.5 \mathrm{ml} / \mathrm{kg}$ BW) and gavaged with $(0.035 \mathrm{mg} / \mathrm{kg} \mathrm{BW})$ of Phitofert ${ }^{\circledR}$ daily. In the tenth and twenty-eighth of the experiment, blood samples were taken by heart puncture for serum collection. In comparison to all other groups, the current results reveal a significant $(p \leq 0.05)$ decrease in testosterone, somatic testicular index, and sperm quality in the $\mathrm{G} 3$ group, nevertheless, there was a significant $(\mathrm{P}<0.05)$ increase in LH, FSH, sperm abnormalities percent, and dead sperm percent in the G3 group. The capacity of Phitofert ${ }^{\bullet}$ to restore all passive effects of CCL4 and increase epididymal sperm quality was demonstrated in G4 groups.
\end{abstract}

Keywords | CCl4, Phitofert ${ }^{\oplus}$, Epididymal sperm, Testicular somatic index, Macca rote

Received | October 25, 2021; Accepted | November 30, 2021; Published | January 05, 2022

${ }^{*}$ Correspondence | Wassan Mhammed Husain, Uruk University, Iraq; Email: Wassan.mh.husain@uruk.edu.iq

Citation | Husain WM, Ali ZS (2022). The effective role of Phitofert ${ }^{\circledR}$ supplement in male reproductive hormones and epididymal sperm quality in carbon tetrachloride (CCL4) treated rats. Adv. Anim. Vet. Sci. 10(2): 292-297.

DOI | http://dx.doi.org/10.17582/journal.aavs/2022/10.2.292.297

ISSN (Online) | 2307-8316

\section{INTRODUCTION}

I nfertility and its complications are important sources of distress in people's lives (Eskandari and Momeni, 2016). Male infertility is commonly caused by an inability to generate a sufficient quantity of active sperms (Amin and Hamza, 2006; Hamid et al.,2018). Many studies have found that oxidative stress can influence sperm generation and count by producing free radicals and oxidizing germ cells in the testis tissue (Agarwal et al., 2014). Tetrachloromethane, commonly known as carbon tetrachloride $\left(\mathrm{CCL}_{4}\right)$, was thought to be colorless, nonflammable, and a heavy liquid with a pleasant, fragrant, nonirritating odor (Lide, 2006). It is employed as a fumigant agriculture and as a solvent in semiconductor manufacture; in fat production in oil, rubber and laboratory uses (Kauppinen et al., 2000). The central nervous system, hepatocyte and renal system can be affected by high amounts of $\mathrm{CCL}_{4}$ (Sönmez et al., 2014). Chronic [CCL4] exposed can induce kidney impairment and cancer in the liver (Masuda, 2006). In addition, sperm motility, sperm concentration and sperm destruction was produced by $\mathrm{CCl} 4$ and relative or absolute alteration in reproductive organ weights (Türk et al., 2016). The nutritional supplement, such as Phitofert ${ }^{\oplus}$, helped improve fertility and adaptogenic and sexual qualities in males due to its components, macca and selenium (A1-Shahery, 2019). Maca dry extract (Lepidium meyenii W., tuber), Colloidal, Maca (Lepidium meyenii W.) Silica, L-methionine (https://www.promopharma.it/en/phitofert-men) are the Phitofert ${ }^{\varpi}$ components. The ingredients are: The Maca plant is found in and belongs to Brassica in South America. It has also been used for the treatment of infertility in several animals, traditional medicine for many illnesses (Gonzales, 2012). For the second component, selenium, 
this was a mineral that was able to alleviate oxidative stress and improve the quality of the sperm (Hamza and AlHarbi, 2014). Current study was aimed for the first time to explore the underlying CCL4 mechanism to impact male fertility as well as to investigate the possibility of the Phitofert $^{\circledR}$ product in males for medicating the adverse effects of CCL4 exposure.

\section{MATERIALS AND METHODS}

\section{EXPERIMENTAL ANIMALS DESIGN}

Twenty-four adult rats aged three and a half-four months, 350-400 gm weight were used in the experiment. They were placed six per cage and put in the acclimatization room for two weeks. Air in the room was kept at (21-25 KF), ventilation air and a light/ dark cycle of 12:12 h/day were used to continually alter the air of the room. Every 2 days, the cage litter was replaced. Pellet of a freshly made meal was used to fed animals. Randomly designed and handled the experimental animals as follows: Randomly, 24 adult rats were placed into four groups and treated as follows for 28 days, G1: animals were given DW and served as control. G2: healthy rats were gavage daily with $0.035 \mathrm{mg} /$ $\mathrm{kg} \mathrm{BW}$ of Phitofert ${ }^{\circledR}$ (Yousif et al., 2018). G3: were treated I.P with $500 \mathrm{mg} / \mathrm{kg}$ B.W. of CCL4 mixing with olive oil (equal volume of olive oil) $(0.5 \mathrm{ml} / \mathrm{kg}$ B.W.) twice a week (Arrack and Wassan, 2017). G4: were treated I.P with 500 $\mathrm{mg} / \mathrm{kg}$ B.W. of CCL4 mixing with (o.5 ml/ $\mathrm{kg}$ B.W.) of olive oil twice a week and gavage daily with $0.035 \mathrm{mg} / \mathrm{kg}$ BW of Phitofert ${ }^{\circledR}$.

\section{SPECIMEN PREPARATION}

Intra muscular injection of $(90 \mathrm{mg} / \mathrm{kg})$ of ketamine and $(40$ $\mathrm{mg} / \mathrm{kg}$ ) of xylacine were used to anesthetizing the animal on the animals. At (Zero, 10, 28) days of research, blood samples were collected using heart puncture methods. Serum was isolated by centrifuged from coagulated blood specimen at $2500 \mathrm{rpm}$ for $15 \mathrm{~min}$ and maintained at -20 ${ }^{\circ} \mathrm{C}$ by freezing until needed (David, 2005). ELISA kit uesd to mussurment of Testosterone, follicular stimulating hormone (FSH), luteinizing hormone (LH) concentration according to Kit manufacturer's instructions. At the end of research rats were anesthetized and weighted, testes weighted by sensitive balance. Somatic testicular index was study through the following calculation:

Relative testicular weight $=($ testes weight $(\mathrm{gm}) /$ body weight $(\mathrm{gm})) \times 100$

\section{SPERM PARAMETER}

rats epididymal of four groups were removed and prepared. The epididymal caudae were individually crushed by microsurgical scissor in one $\mathrm{ml}$ of Ham's solution to release the spermatozoa. The sperms suspension was kept at $\left(37^{\circ} \mathrm{C}\right)$ in a humid atmosphere of ( $5 \% \mathrm{CO} 2)$, one drop of sperms suspension was examined under microscope to determine the sperm quantity such as morphology, concentration, viability and motility (A1-Shahery, 2019).

\section{STATISTICAL ANALYSis}

The program was used to Least significant difference-LSD test and Duncan Multiple Range (ANOVA) was used to significant compare between means in this study by using Statistical Analysis System- SAS (2012) program.

\section{RESULTS AND DISCUSSION}

\section{SERUM HORMONES PARAMETERS}

Testosterone Concentration (NG\ML)

Table 1 revealed a significant $(p \leq 0$. 05) decline in testosterone levels in G3 when compared to the control and all other administered groups during the period of this study; moreover, testosterone levels within groups showed a significant decrease in (10 and 28) days when compared to zero time. Whereas testosterone levels increased $(\mathrm{P}<0.05)$ significantly in the $\mathrm{G} 2$ group when compared to the control group, they also increased $(\mathrm{P}<0.05)$ significantly within the same group when compared to zero time and ten days of administration. The G4 group exhibited no significant changes when compared to the control group, but showed a significant rise $(\mathrm{P}<0.05)$ in testosterone levels when compared to the G3 groups. The G4 group exhibited no significant changes when compared to the control group, but showed a significant $(\mathrm{P}<0.05)$ rise in testosterone levels when compared to the $\mathrm{G} 3$ groups. In contrast, testosterone levels in $\mathrm{G} 4$ were significantly $(\mathrm{P}<0.05)$ higher in $(28$ day) as compared to (zero and 10) days of the study period. Finally, testosterone level in G3 group showed a significant decrement $(\mathrm{P}>0.05)$ when compared zero time in the same group and when compared with all treated groups.

Table 1: Effect of CCl4, Phitofert ${ }^{\circledR}$ and $\left(\right.$ Phitofert ${ }^{\circledR}+$ CCl4) on testosterone hormone level $(\mathrm{ng} / \mathrm{ml})$ in adult male rats $M \pm S . E .(n=6)$.

$\begin{array}{llll}\text { Groups } & \text { Zero time } & \mathbf{1 0} \text { days } & \text { 28 days } \\ \text { G1 } & 1.50 \pm 0.04 & 1.68 \pm 0.23 & 1.61 \pm 0.51 \\ & \mathrm{~A} \mathrm{a} & \mathrm{B} \mathrm{b} & \mathrm{B} \mathrm{a} \\ \mathrm{G} 2 & 1.47 \pm 0.05 & 2.73 \pm 0.16 & 3.83 \pm 0.12 \\ & \mathrm{~A} \mathrm{c} & \mathrm{A} \mathrm{b} & \mathrm{A} \mathrm{a} \\ \mathrm{G} 3 & 1.49 \pm 0.21 & 0.59 \pm 1.10 & 0.37 \pm 0.31 \\ & \mathrm{~A} \mathrm{a} & \mathrm{C} \mathrm{b} & \mathrm{C} \mathrm{b} \\ \text { G4 } & 1.51 \pm 0.23 & 1.45 \pm 0.41 & 2.47 \pm 0.56 \\ & \mathrm{~A} \mathrm{~b} & \mathrm{~B} \mathrm{~b} & \mathrm{~B} \mathrm{a}\end{array}$

$\mathrm{LSD}=1.02$; G1: healthy control group; G2: animals received (0.035) of Phitofert ${ }^{\circledR}$; G3: animals received (500 mg / kg. B.W.) of ccl4; G4: animals received (500 $\mathrm{mg}$ of ccl4 + $0.035 \mathrm{mg}$ of Phitofert $\left.{ }^{\circledR}\right)$. Various capital letter denote significant differences between groups $(P<0.05)$. Various small letter denote significant differences within groups $(\mathrm{P}<0.05)$. 


\section{LUTEINIZING HORMONE}

CONCENTRATION

\section{(LH)}

CONCENTRATION (MLU\ML)

As opposed to controls and all administered groups, Table 2 shows a significant $(\mathrm{P}<0.05)$ rise in $\mathrm{LH}$ concentration in the G3 group. In addition, the concentration of $\mathrm{LH}$ was significantly $(\mathrm{P}<0.05)$ increased in the 28 -day period compared with 0 and 10 days of the administration, whereas G2 showed a significant $(\mathrm{P}>0.05)$ decline compared to the control, and all animals were given and over zero and 10 days in the same group. The result from the G4 Group revealed that there were significant variations between the control group and G4 group in the concentration of $\mathrm{LH}$ and within 28 days when compared with zero time and 10 days after administered.

Table 2: Effect of CCl4, Phitofert ${ }^{\circledR}$ and $\left(\right.$ Phitofert $^{\circledR}+$ CC14) on $\mathrm{LH}$ hormone level $(\mathrm{ng} / \mathrm{ml})$ in adult male rats $\mathrm{M} \pm$ S.E. $(\mathrm{n}=6)$.

$\begin{array}{llll}\text { Groups } & \text { Zero time } & \mathbf{1 0} \text { days } & \mathbf{2 8} \text { days } \\ \text { G1 } & 1.81 \pm 0.31 & 1.85 \pm 0.03 & 1.78 \pm 0.01 \\ & \mathrm{~A} \mathrm{a} & \mathrm{B} \mathrm{a} & \mathrm{B} \mathrm{a} \\ \mathrm{G} 2 & 1.83 \pm 0.02 & 1.28 \pm 0.16 & 0.70 \pm 0.13 \\ & \mathrm{~A} \mathrm{a} & \mathrm{C} \mathrm{a} & \mathrm{C} \mathrm{b} \\ \mathrm{G} 3 & 1.79 \pm 0.11 & 2.59 \pm 0.13 & 3.67 \pm 0.16 \\ & \mathrm{~A} \mathrm{c} & \mathrm{A} \mathrm{b} & \mathrm{A} \mathrm{a} \\ \mathrm{G} 4 & 1.80 \pm 0.21 & 1.83 \pm 0.31 & 2.02 \pm 0.27 \\ & \mathrm{~A} \mathrm{~b} & \mathrm{~B} \mathrm{~b} & \mathrm{~B} \mathrm{a}\end{array}$

$(0.035)$ of Phitofert ${ }^{\circledR} ;$ G G : animals received $(500 \mathrm{mg} / \mathrm{kg}$. B.W.) of ccl4; G4: animals received (500 $\mathrm{mg}$ of ccl4 + $0.035 \mathrm{mg}$ of Phitofert $\left.{ }^{\circledR}\right)$. Various capital letter denote significant differences between groups $(\mathrm{P}<0.05)$. Various small letter denote significant differences within groups $(\mathrm{P}<0.05)$.

\section{Follicular STIMULATING HORMONE (FSH)} CONCENTRATION (MLU\ML)

Table 3 depicted FSH level in rats during the testing period, in comparison with control and other managed groups, the G3 group exhibited a significant $(\mathrm{P}<0.05)$ rise in $F S H$ level. In 28 days of administration within the G3 group, FSH was also significantly $(\mathrm{P}<0.05)$ increased compared to zero and 10 days of the administration, while in comparison to control and all managed animals and in relation to zero and 10 days of administration within the same group, FSH level showed a significant $(\mathrm{P}>0.05)$ decrease in G2. FSH levels in the 10 and 28 days administration in comparison to zero-times are shown by the results from G4 group rats.

\section{SPERM PARAMETERS}

Table 4 shows a significant $(\mathrm{P}<0.05)$ increase in sperm percentage and sperm concentration in G2 as opposed to control groups and other groups, and there was a significant $(\mathrm{P}>0.05)$ decrease in sperm abnormalities as a percentage and death sperm percentage in G2 groups. The results show that the percentage of dead sperms and abnormalities in $\mathrm{G} 3$ have significantly $(\mathrm{P}<0.05)$ increased.
In contrast, the outcome of the G4 sperm parameter showed non- significant differences in comparison to the control group, but the G4 sperm motility percentage and sperm concentration increased significantly $(\mathrm{P}<0.05)$ in comparison to the $\mathrm{G} 3$ sperm group, while the sperm abnormality percentage declined significantly $(\mathrm{P}>0.05)$ as compared with the G3 group.

Table 3: Effect of CCl4, Phitofert ${ }^{\circledR}$ and $\left(\right.$ Phitofert $^{\circledR}+$ $\mathrm{CCl} 14)$ on FSH hormone level $(\mathrm{ng} / \mathrm{ml})$ in adult male rats. $\mathrm{M} \pm \mathrm{S}$.E. $(\mathrm{n}=6)$.

$\begin{array}{llll}\text { Groups } & \text { Zero time } & \text { 10 days } & \text { 28 days } \\ \text { G1 } & 5.8 \pm 0.31 & 5.56 \pm 0.23 & 5.50 \pm 0.21 \\ & \mathrm{~A} \mathrm{a} & \mathrm{B} \mathrm{a} & \mathrm{B} \mathrm{a} \\ \mathrm{G} 2 & 5.72 \pm 0.03 & 4.36 \pm 0.14 & 3.16 \pm 0.11 \\ & \mathrm{~A} \mathrm{a} & \mathrm{C} \mathrm{b} & \mathrm{C} \mathrm{c} \\ \text { G3 } & 5.80 \pm 0.13 & 6.76 \pm 0.12 & 8.13 \pm 0.01 \\ & \mathrm{~A} \mathrm{c} & \mathrm{A} \mathrm{b} & \mathrm{A} \mathrm{a} \\ \text { G4 } & 5.74 \pm 0.23 & 5.24 \pm 0.22 & 4.32 \pm 0.02 \\ & \mathrm{~A} \mathrm{a} & \mathrm{B} \mathrm{a} & \mathrm{B} \mathrm{b}\end{array}$

$\mathrm{LSD}=0.55$; G1: healthy control group; $\mathrm{G} 2$ : animals received (0.035) of Phitofert ${ }^{\circledR}$; G3: animals received $(500 \mathrm{mg} / \mathrm{kg}$. B.W.) of $\mathrm{CCl}_{4}$; G4: animals received $(500 \mathrm{mg}$ of ccl $4+0.035 \mathrm{mg}$ of Phitofert ${ }^{\circledR}$ ). Various capital letter denotes significant differences between groups $(\mathrm{P}<0.05)$. Various small letter denotes significant differences within groups $(\mathrm{P}<0.05)$.

Table 4: Effect of CCl4, Phitofert ${ }^{\circledR}$ and $\left(\right.$ Phitofert $^{\circledR}+$ CC14) on sperms parameters in adult male rats after 28 days of experiment $M \pm S . E .(n=6)$.

\begin{tabular}{|c|c|c|c|c|}
\hline Groups & Motility \% & Dead \% & $\begin{array}{l}\text { Abnormali- } \\
\text { ty \% }\end{array}$ & $\begin{array}{l}\text { Concentra- } \\
\text { tion }\left(\mathbf{x 1 0}^{7}\right)\end{array}$ \\
\hline G1 & $\begin{array}{l}88.31 \pm 0.05 \\
\text { B }\end{array}$ & $\begin{array}{l}6.40 \pm 0.31 \\
\mathrm{C}\end{array}$ & $\begin{array}{l}8.30 \pm 0.51 \\
D\end{array}$ & $\begin{array}{l}32.40 \pm 0.52 \\
\text { B }\end{array}$ \\
\hline G2 & $\begin{array}{l}93.05 \pm 0.30 \\
\text { A }\end{array}$ & $\begin{array}{l}10.04 \pm 0.51 \\
\text { B }\end{array}$ & $\begin{array}{l}5.03 \pm 0.13 \\
\mathrm{C}\end{array}$ & $\begin{array}{l}40.30 \pm 0.41 \\
\text { A }\end{array}$ \\
\hline G3 & $\begin{array}{l}40.02 \pm 1.02 \\
\text { A }\end{array}$ & $\begin{array}{l}12.15 \pm 0.36 \\
\text { A }\end{array}$ & $\begin{array}{l}20.31 \pm 0.51 \\
\text { A }\end{array}$ & $\begin{array}{l}15.02 \pm 0.13 \\
\text { C }\end{array}$ \\
\hline G4 & $\begin{array}{l}73.21 \pm 1.01 \\
\text { C }\end{array}$ & $\begin{array}{l}7.02 \pm 0.61 \\
\text { C }\end{array}$ & $\begin{array}{l}15.00 \pm 0.53 \\
\mathrm{~B}\end{array}$ & $\begin{array}{l}30.21 \pm 0.83 \\
\text { B }\end{array}$ \\
\hline LSD & 37.4 & 1.93 & 2.20 & 5.32 \\
\hline
\end{tabular}

G1: healthy control group; G2: animals received (0.035) of Phitofert ${ }^{\circledR}$; G3: animals received (500 mg / kg. B.W.) of ccl4; G4: animals received (500 $\mathrm{mg}$ of ccl4 $+0.035 \mathrm{mg}$ of Phitofert $\left.{ }^{\circledR}\right)$. Various capital letter denote significant differences between groups $(\mathrm{P}<0.05)$. Various small letter denote significant differences within groups $(\mathrm{P}<0.05)$.

\section{Testicular SOMATIC INDEX}

In Table 5 the testicular somatic index was shown, the associated weight of the tests showed a significant $(\mathrm{P}<0.05)$ increase in $\mathrm{G} 2$ rats compared to the administrative groups, while the $\mathrm{G} 3$ group showed a significant $(\mathrm{P}>0.05)$ decline in the weight of the tests compared to all administrated groups. 
Table 5: Effect of CCl4, Phitofert ${ }^{\circledR}$ and $\left(\right.$ Phitofert $\left.{ }^{\circledR}+\mathrm{CCl} 4\right)$ on testicular index (gm) in adult male rats after 28 days of experiment $M \pm S$.E. $(n=6)$.

$\begin{array}{lllll}\text { Groups } & \text { G1 } & \text { G2 } & \text { G3 } & \text { G4 } \\ \text { Testicular weight to body weight ratio } & 0.364 \pm 0.01 & 0.606 \pm 0.01 & 0.300 \pm 0.02 & 0.432 \pm 0.01 \\ & \text { B } & \text { A } & \text { C } & \text { B }\end{array}$

LSD $=0.12$; G1: healthy control group; G2: animals received (0.035) of Phitofert ${ }^{\circledR}$; G3: animals received (500 mg / kg. B.W.) of ccl4; G4: animals received (500 mg of ccl4 $+0.035 \mathrm{mg}$ of Phitofert $\left.{ }^{\circledR}\right)$. Various capital letter denote significant differences between groups $(\mathrm{P}<0.05)$.

The significant $(\mathrm{P}<0.05)$ decrease in the testicular somatic index also testosteronelevel following CCL4 administration (Tables 1 and 5) may be due to CCL4 toxicity. It may be producing ROS and influencing testicular weight, germline, and testosterone levels. Indeed, male infertility can be induced directly by free radicals or indirectly by altering male hormone homeostasis, resulting in reproductive failure (Hashem, 2021). Furthermore, a decrease in testosterone levels may be caused by the suppression of enzymatic pathways of hormones synthesis in the testes or adrenal gland, as well as interference with gonadotropin releasing hormone $(\mathrm{GnRH})$ production, both of which induce a decrease in testosterone synthesis and release (Pineda and Dooley, 2003). The active ingredients maca plant extract and Selenium may contribute to the beneficial effect of Phitofert ${ }^{\circledR}$ on testicular tissue via a significant $(\mathrm{P}>0.05)$ increase in testicular somatic index and testosterone production. According to the most recent research on the effects of maca on testicular gene expression for luteinizing hormone receptor, steroidogenic acute regulatory protein, and steroidogenic enzymes, maca increases testicular mRNA level for 3-hydroxysteroid dehydrogenase (3 $\beta$-HSD), an enzyme involved in androgen production. Enhanced $3 \beta-\mathrm{HSD}$ activity may enhance androstenedione, a precursor of testosterone, improving testosterone synthesis, this may also be linked to changes in the activity of reactive oxygen species (Sánchez et al., 2017). Yoshida et al. (2018) reported the same results of temporary testosterone rise by Leydig cells after feeding maca extracts for lengthy periods of time, indicating that maca may relieve the loss in steroidogenic capacity of Leydig cells with age. The treatment of Phitofert ${ }^{\circledR}$ with CCL4 resulted in the restoration of normal testicular weight and testosterone levels. This finding indicated the involvement of Phitofert ${ }^{\circledR}$ as a scavenger of free radicals produced by CCl4. Phitofert ${ }^{\circledR}$ is a dietary supplement that contains numerous components such as adaptogenic and tonic plant extracts Maca, Ginseng and Withania. On the other hand, this medication contains certain vitamins, such as $\mathrm{C}$ and B12, that play a role in cell division (A1-Shahery 2019).

The other component was selenium, which inhibits mitophagy in Sertoli cells, regulates immunological genes and proteins in the blood-testis barrier, enhances testosterone production from Leydig cells, and increases the width of the seminiferous tubules (Khoshbakht et al., 2020). Our investigation found a significant $(\mathrm{P}>0.05)$ increase in both LH and FSH levels in CCL4-treated rats and a significant $(\mathrm{P}<0.05)$ decrease in both hormones in Phitofert ${ }^{\circledR}$-treated rats, with no significant changes in the CCL4 and Phitofert ${ }^{\circledR}$-treated groups (Tables 2 and 3).

These hormonal alterations are caused by the feedback mechanism and hormonal control associated with testosterone levels in these populations. Gonadal malfunction and testicular atrophy caused by a drop in testosterone concentration were prompted pituitary gland to produce $\mathrm{LH}$ and $\mathrm{FSH}$ in rats in the $\mathrm{G} 4$ group, restoring the level to normal. Furthermore, CCL4 toxicity alters the pituitary-gonadal system, causing an increase in $\mathrm{LH}$ and FSH production to promote spermatogenesis (Arrack and Wassan, 2017). The restoration of LH and FSH production in the G4 group suggested that Phitofert ${ }^{\circledR}$ has antioxidant action due to bioactive constituents in this product such as selenium, which controls oxidative stress and increases anti-apoptotic proteins (like as bc12) (Khoshbakht et al., 2020).

Finally, (Table 4) shows the effect of Phitofert ${ }^{\circledR}$ on sperm parameters, as well as the effect of CCL4 on testicular sperm production and sperm parameters. Following that, the unfavorable changes in the functional characteristics of the testes caused by oxidative stress produced by CCL4 in (G2) were passively reflected in the testes' ability to produce sperms and sperm quality. As a result, it was shown to have a decrease in sperm concentration, viability, normal morphology, and a regression in motility when compared to G1. On the other hand, it was discovered that the Phitofert ${ }^{\circledR}$ supplement can reduce CCL4 toxicity in the testicles and epididymis. The administration of Phitofert ${ }^{\circledR}$ (G4) to CCL4 rats reduced oxidative stress in testicular and epididymal tissue via a significant $(p<0.05)$ increase in testicular sperm production. Our findings might be attributable to a balance of oxidant-antioxidant state in testicular and epididymal tissue via its components, which included maca plant extract and selenium supplement (AlShahery, 2019).

Furthermore, our findings were consistent with many earlier studies that demonstrated the efficacy of Phitofert ${ }^{\circledR}$ in modulating the failure of various reproductive aspects 
through the significant function of its component, maca. According to Gonzales et al. (2003) treatment with alcoholic extract of maca at dosages (48mg/day or $96 \mathrm{mg} /$ day) for three weeks produced a progression of spermatogenesis when the distances of stages of seminiferous epithelium in rats were raised. Additionally, Gonzales et al. (2006) discovered that treating rats using aqueous extract of black maca (2mg.Kg-1) over 12 days resulted in improved impacts on spermatogenesis; hence, in the spermatonenic cycles, daily spermatogenesis was continuous until day (12) when compared to the control. Finally, all of the negative effects of CCL4 treatment on testicular function were caused by an oxidative deficiency in this tissue, which reflected on sperm parameters. Meanwhile, Phitofert ${ }^{\circledR}$ was able to repair this damage through the systemization of its components such as maca and selenium, both of which have antioxidant effects. As a result, Phitofert $^{\circledR}$ may be used as a supplement to minimize the effect of free radicals on testicular tissue and restore testicular function.

\section{ACKNOWLEDGEMENTS}

I'd want to thank everyone who assisted me with this research.

\section{NOVELTY STATEMENT}

This is the first report to conduct a study using rats to determine effect of of Phitofert ${ }^{\circledR}$ on CCL4 treated rats and their effect on sperm quality.

\section{AUTHOR'S CONTRIBUTION}

All authors design and performing experiment. Zainab Sattar Ali, performed data analysis, interpretation, and literature. All of the author preparing and writing the manuscript

\section{CONFLICT OF INTEREST}

The authors have declared no conflict of interest.

\section{REFERENCES}

Agarwal, Ashok, Gurpriya V, Chloe O, Stefan SDP (2014). Effect of oxidative stress on male reproduction. World J. Mens Health, 32(1): 1. https://doi.org/10.5534/wjmh.2014.32.1.1

Ahmed, Measer A, Hussien MT, Aziz KH (2018). Silymarin Effect as an Antioxidant to Improve Damages Induced by CCl4 on Some Characteristics of Male Rats Reproductive System.” Tikrit Journal of Pure Science 23(9): 1813-1662. https://doi.org/10.25130/tjps.23.2018.029

Al-Shahery NJMS (2019). Role of phitofert in sperm functions and biochemical parameters of indomethacin-treated rats. Int. J. Pharm. Res., 11(2): 67-75. https://doi.org/10.31838/ ijpr/2019.11.02.013
Al-Shahery NJMS (2019). Role of phitofert in sperm functions and biochemical parameters of indomethacin-treated rats. Int. J. Pharm. Res., 11(4): 2. https://doi.org/10.31838/ ijpr/2019.11.02.013

Amin A, Hamza AA (2006). Effects of roselle and ginger on cisplatin-induced reproductive toxicity in rats. Asian J. Androl., 8(5): 607-612. https://doi.org/10.1111/j.17457262.2006.00179.x

Arrack JK, Wassan MH (2017). Protective role of pomegranate peel extract on the pituitary gland of adult male rabbits treated with CCL4.

David W (2005). The Immunoassay Handbook. Thired edition. Oxford, U.K.

Eskandari F, Hamid RM (2016). Protective effect of silymarin on viability, motility and mitochondrial membrane potential of ram sperm treated with sodium arsenite. Int. J. Reprod. BioMed., 14(6): 397. https://doi.org/10.29252/ ijrm.14.6.397

Gonzales GF (2012). Ethnobiology and ethnopharmacology of lepidium meyenii (Maca), a plant from the peruvian highlands. Evidence Based Complemen. Altern. Med., 2012. https://doi.org/10.1155/2012/193496

Gonzales GF, Julio R, Arturo C, Manuel G, Leon V (2003). Effect of alcoholic extract of lepidium meyenii (Maca) on testicular function in male rats. Asian J. Androl., 5(4): 349.

Gonzales, Gustavo F, Nieto J, Julio R, Mauel G (2006). Effect of black maca (Lepidium Meyenii) on one spermatogenic cycle in rats. Andrologia, 38(5): 166-172. https://doi. org/10.1111/j.1439-0272.2006.00733.x

Hamid AK, Ahmed MA, Tayawi HM (2018). Silymarin effect as an antioxidant to improve damages induced by $\mathrm{CCl} 4$ on some characteristics of male rats reproductive system. Tikrit J. Pure Sci. 23(2): 60-65.

Hamza RZ, Al-Harbi MS (2014). Monosodium glutamate induced testicular toxicity and the possible ameliorative role of vitamin e or selenium in male rats. Toxicol. Rep., 1: 10371045. https://doi.org/10.1016/j.toxrep.2014.10.002

Hashem AS (2021). Defensive impact of propolis against CC14 actuated rats testicular damage. 7710(March): 70-77. https://doi.org/10.5455/javar.2021.h487

Kauppinen T, Jouni T, David P, Randy Y, Wolfgang A, Paolo B, Johnni H, Hans K, Jeronimo MB, Dario M (2000). Occupational exposure to carcinogens in the European union. Occup. Environ. Med., 57(1): 10-18. https://doi. org/10.1136/oem.57.1.10

Khan RA (2012). Protective effects of Sonchus asper (L.) Hill, (Asteraceae) against $\mathrm{CCl} 4$-Induced oxidative stress in the thyroid tissue of rats. BMC Complement. Altern. Med., 12(1): 1-8. https://doi.org/10.1186/1472-6882-12-181

Khoshbakht S, Fatemeh M, Sareh K, Narjes J, Alireza E (2020). Protective effects of selenium on electromagnetic fieldinduced apoptosis, aromatase P450 activity, and leptin receptor expression in rat testis. pp. 19.

Lide DR (2006). Chemical rubber company (CRC). Handbook of chemistry and physics, $86^{\text {th }}$ Edn.CRC Press, Boca Raton, Florida. 3-470.

Masuda Y (2006). Learning toxicology from carbon tetrachlorideinduced hepatotoxicity. Yakugaku Zasshi J. Pharm. Soc. Japan, 126(10): 885-899. https://doi.org/10.1248/ yakushi.126.885

Pineda MH, Michael PD (2003). McDonald's veterinary endocrinology and reproduction. Iowa state press.

Sánchez JML, Serrano ZA, Durán JA, Morales HSG, Álvarez 
PBM (2017). Peruvian maca and possible impact on fertility. J. Nutr. Health Food Eng. Peruvian, 6(5): 5-7. https://doi. org/10.15406/jnhfe.2017.06.00217

SAS (2012). Statistical Analysis System, User's Guide. Statistical. Version 9. Cary. N.C. USA.

Sönmez M, Türk G, Çeribaşı S, Çiftçi M, Yüce A, Güvenç M, Özer Kaya Ş, Cay M, Aksakal M (2014). Quercetin attenuates carbon tetrachloride-induced testicular damage in rats. Andrologia, 46(8): 848-858. https://doi.org/10.1111/ and.12159

Türk G, Songül Ç, Mustafa S, Mehmet Ç, AbdurraufY, Mehmet G, Şeyma ÖK, Mehmet C, Mesut A (2016). Ameliorating effect of pomegranate juice consumption on carbon tetrachloride-induced sperm damages, lipid peroxidation, and testicular apoptosis. Toxicol. Ind. Health, 32(1): 126137. https://doi.org/10.1177/0748233713499600

Yoshida K, Ohta Y, Kawate N, Takahashi M, Inaba T, Hatoya S, Morii H, Takahashi K, Ito M, Tamada H (2018). Long-term feeding of hydroalcoholic extract powder of lepidium meyenii (Maca) enhances the steroidogenic ability of leydig cells to alleviate its decline with ageing in male rats. Andrologia, 50(1): e12803. https://doi.org/10.1111/and.12803

Yousif M, Saad A-D, Jawad A (2018). Effect of phitofert ${ }^{\circledR}$ on testicular function of vasectomized mature mice. AlAnbar J. Vet. Sci., 11(2): 9-16. https://doi.org/10.37940/ AJVS.2018.11.2.2 